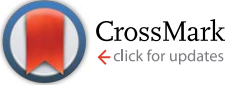

Cite this: RSC Adv., 2017, 7, 12503

\title{
Synchronous recovery of iron and electricity using a single chamber air-cathode microbial fuel cell $\uparrow$
}

\author{
Xiufen Li, ${ }^{\text {ab }}$ Yan Zheng, ${ }^{\text {ab }}$ Pengfei Nie, ${ }^{\text {ab }}$ Yueping Ren, ${ }^{\text {ab }}$ Xinhua Wang ${ }^{\text {ab }}$ \\ and Yanfei Liuc
}

In recent years, microbial fuel cell (MFC) technology has become an attractive option for metal recovery/ removal at the cathode combined with electricity generation, using organic substrates as electron donor at the anode. With no organic substrate supply, a single chamber air-cathode MFC was used to synchronously recover metal and electricity from a real stream containing high-strength metal, sulfate, strong acid and acidophilic chemoautotrophic bacteria (ACB). Instead, ferrous ions were used as electron donor which made the single chamber air-cathode MFC applicable for the (bio)leachate and mining/metallurgical stream sites possibly lacking organics. We showed that $71.8 \%$ iron was recovered, and $95.9 \%$ ferrous ions were removed from a real iron-laden stream. At the same time, $360.1 \mathrm{mV}$ cell voltage was achieved with $88.1 \%$ of coulombic efficiency. In the presence of ACB microbes, the iron recovery and power density were increased by $8.6 \%$ and $29.2 \%$, respectively, via promoting the anode electron transferring and preventing sulfur passivation of electrodes. Iron in the form of $\mathrm{FeOOH}$ (goethite) was recovered mainly at the anode via the ferrous oxidization to $\mathrm{Fe}(\mathrm{OH})_{3}$. At the cathode, ferrous ions directly combined with oxygen and electrons into $\mathrm{FeO}$, and further into $\mathrm{Fe}_{2} \mathrm{O}_{3}$. It was prospective at sites lack of organics to synchronously recover metals and electricity from real metalladen streams using single chamber air-cathode MFC technology.

Received 13th December 2016
Accepted 2nd February 2017

DOI: 10.1039/c6ra28148f

rsc.li/rsc-advances laden streams, using organic substrates as electron donor at the anode..$^{8-10}$

Removal/recovery of metals from metal-laden streams was widely studied using dual or single chamber MFCs, in which metals were removed in the anaerobic or anoxic cathode chamber through cathode metal reduction, while organic substrates were used as the carbon and electron donor in the anode chamber. ${ }^{11-16} \mathrm{Cr}(\mathrm{vI})$ and $\mathrm{V}(\mathrm{v})$ were simultaneously reduced at the cathode in a double-chamber MFC. ${ }^{16}$ With $20 \mathrm{mmol} \mathrm{L}^{-1}$ acetate as electron donor, copper removal of $>99 \%$ from the $\mathrm{CuCl}_{2}$ catholyte $\left[1 \mathrm{~g} \mathrm{~L}^{-1} \mathrm{Cu}\right.$ (II) $]$ were achieved over 6 to 7 days of MFC operation. ${ }^{11}$ In a dual-chamber MFC, removal efficiencies of $97.8 \%$ and $94.6 \%$ were achieved for initial concentrations of 50 and $100 \mathrm{mg} \mathrm{L}^{-1} \mathrm{Au}(\mathrm{III})$, respectively, over $12 \mathrm{~h}^{17} \mathrm{~A}$ maximum power output of $0.89 \mathrm{~W} \mathrm{~m}^{-2}$ was outputted for $100 \mathrm{mg} \mathrm{L}^{-1} \mathrm{Au}(\mathrm{III})$. Removal of $\mathrm{Au}(\mathrm{III})$ from the catholyte was associated with deposition of metallic $\mathrm{Au}(0)$ on the cathode surface. The single chamber air-cathode microbial fuel cells achieved the power density of $3.6 \mathrm{~W} \mathrm{~m}^{-2}$, and removed $90 \% \mathrm{Cd}$ and $97 \% \mathrm{Zn}$ mainly by bio-sorption and sulfide precipitation, from $200 \mu \mathrm{mol} \mathrm{L}^{-1} \mathrm{Cd}$ and $400 \mu \mathrm{mol} \mathrm{L}^{-1} \mathrm{Zn}$ solutions, respectively. ${ }^{18}$ As reported above, metal was generally used as the electron acceptor at the cathode, and organics was as the electron donor at the anode. It was not always applicable for the (bio)leachate and mining/metallurgical stream sites possibly lack of organics.
${ }^{a}$ Laboratory of Environmental Biotechnology, School of Environmental and Civil Engineering, Jiangnan University, Wuxi 214122, PR China. E-mail: xfli@jiangnan. edu.cn; Tel: +8651085326516

${ }^{b}$ Jiangsu Key Laboratory of Anaerobic Biotechnology, Wuxi 214122, PR China ${ }^{c}$ School of Chemistry and Chemical Engineering, Central South University, Changsha 410083, PR China

$\dagger$ Electronic supplementary information (ESI) available. See DOI: 10.1039/c6ra28148f 
In a double chamber fuel cell reactor with an anion exchange membrane, $\mathrm{Fe}^{2+}$ was abioticly removed from synthetic acid-mine drainage (ADM) water through oxidizing to insoluble $\mathrm{Fe}(\mathrm{III})$ $\left[\mathrm{Fe}(\mathrm{OH})_{3}\right]$, which precipitated at the bottom of the anode chamber or on the anode electrode via eqn (1). ${ }^{19}$ Optimum conditions were a $\mathrm{pH}$ of 6.3 and a ferrous iron concentration above $\sim 0.0036 \mathrm{~mol} \mathrm{~L}^{-1}$. Further, $\mathrm{Fe}_{2} \mathrm{O}_{3}$ particle diameters ranged from 120 to $700 \mathrm{~nm}$, with sizes that could be controlled by varying the conditions in the fuel cell, were harvested. ${ }^{20}$ However, real (bio)leachate and mining/metallurgical streams contained high-strength metals and sulfate as well as acidophilic chemoautotrophic bacteria (ACB), ${ }^{21}$ which made the metal recovery/ removal complicated. Moreover, it became unknown how the presence of sulfate and ACB microbes influenced electricity generation from those metal-laden streams.

$$
\begin{aligned}
\mathrm{Fe}^{2+}+3 \mathrm{H}_{2} \mathrm{O} \rightarrow \mathrm{Fe}(\mathrm{OH})_{3} \downarrow & +3 \mathrm{H}^{+}+\mathrm{e}^{-}, \\
& \left(\Delta_{\mathrm{f}} G^{0}=+77.49 \mathrm{~kJ} \mathrm{~mol}^{-1}\right)
\end{aligned}
$$

Here, we used single chamber air-cathode MFCs to recover metals combined with electricity generation from real stream contained $50.1 \mathrm{mmol} \mathrm{L}{ }^{-1} \mathrm{Fe}^{2+}, 14.1 \mathrm{mmol} \mathrm{L}^{-1} \mathrm{Fe}^{3+}$ and $52.1 \mathrm{mmol} \mathrm{L}^{-1} \mathrm{SO}_{4}{ }^{2+}$ as well as ACB microbes. The metal precipitates were identified using scanning electron microscopy (SEM) and X-ray photoelectron spectroscopy (XPS), and metal recovery mechanism was analyzed. We showed here that, with no organic substrates as electron donor, $71.8 \%$ iron was recovered and $343.31 \mathrm{~mW} \mathrm{~m}^{-2}$ power density was achieved with $88.1 \%$ of coulombic efficiency. In the presence of ACB microbes, the iron recovery and power density were increased by $8.6 \%$ and $29.2 \%$, respectively, via promoting the anode electron transferring and preventing sulfur passivation of electrodes. The results might be useful for the investigations that metals were recovered using MFCs, with no organics as electron donor, from (bio)leachate and mining/metallurgical streams contained high-strength metal, sulfate, strong acid and ACB microbes.

\section{Materials and methods}

\subsection{Setups and bioleaching solution}

Equipped with air-cathodes, single-chamber MFC reactors with an internal volume of $28 \mathrm{~mL}$ were used in this study (Fig. 1). With a normalized surface area of $7.1 \mathrm{~cm}^{2}$ (one side), anodes were made of pretreated graphite felt (non wet-proofed, Beijing Sanye Cabon Co. Ltd., China). The cathode was prepared through applying platinum powder $\left(0.5 \mathrm{mg} \mathrm{cm}^{-2} \mathrm{Pt}\right.$, Hispec 3000, Shanghai Hesen Electric Co. Ltd., China) and four diffusion layers (polytetrafluoroethylene, PTFE) on $30 \mathrm{wt} \%$ watertight carbon cloth (HCP 330P, Shanghai Hesen Electric Co. Ltd., China) as previously described. ${ }^{19}$ Both electrodes paralleled to each other with a distance of $1.5 \mathrm{~cm}$ and were connected by a piece of titanium wire across an external loading of $500 \Omega$.

The real iron-laden stream used here was obtained by bioleaching FeS power as previously described. ${ }^{22}$ The mixture of 10 $\mathrm{mL}$ effluent, from the existing well-running membrane bioreactor (MBR) treating synthetized municipal wastewater in our lab, and $90 \mathrm{~mL}$ anode medium $\left[0.20 \mathrm{~g} \mathrm{~L}^{-1}\left(\mathrm{NH}_{4}\right)_{2} \mathrm{SO}_{4}, 3.93 \mathrm{~g} \mathrm{~L}^{-1}\right.$

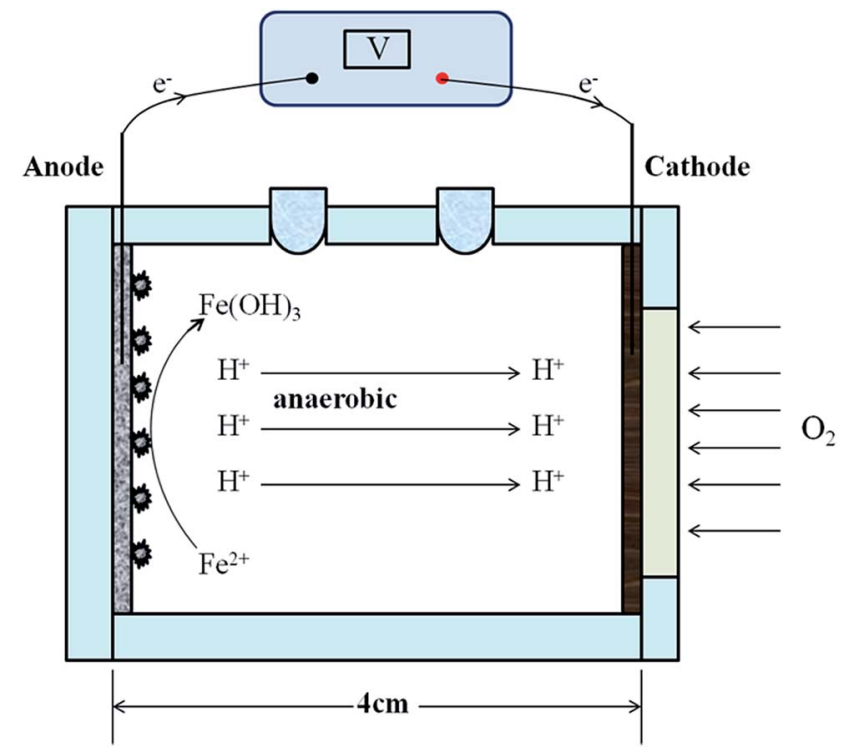

Fig. 1 Schematic diagram of single chamber air-cathode MFC reactor. It had an internal volume of $28 \mathrm{~mL}$. With a normalized surface area of $7.1 \mathrm{~cm}^{2}$, the anode paralleled to the cathode with a distance of $1.5 \mathrm{~cm}$ and were connected by a piece of titanium wire across an external loading of $500 \Omega$

$\mathrm{K}_{2} \mathrm{HPO}_{4} \cdot 3 \mathrm{H}_{2} \mathrm{O}, 0.50 \mathrm{~g} \mathrm{~L}^{-1} \mathrm{MgSO}_{4} \cdot 7 \mathrm{H}_{2} \mathrm{O}, 0.19 \mathrm{~g} \mathrm{~L}^{-1} \mathrm{CaCl}_{2}$, and $10.00 \mathrm{~g} \mathrm{~L}^{-1}$ elemental sulfur] was adjusted to $\mathrm{pH}=2.5$ and transferred into $250 \mathrm{~mL}$ serum bottles. The bottles were put in a shaker of $150 \mathrm{rpm}$, and cultivated for at $30{ }^{\circ} \mathrm{C}$. One month later, the bottles were taken out of the shaker and naturally settled. The supernatant was refreshed using the anode medium and continued to cultivate as described above. Three months later, the inocula contained ACB microbes were obtained ${ }^{23}$ and its $\mathrm{pH}$ level was $~ 2.5$. ACB microbes could grow well in strong acid solution and tolerated high-strength metals under both anaerobic and aerobic environment. ${ }^{\mathbf{2 4 , 2 5}}$ Importantly, ACB microbes had ability to take $S^{0}$ as electron donor (during which $S^{0}$ was oxidized to $\mathrm{SO}_{4}{ }^{2-}$ ) and ferric ions or electrode as electron acceptor, consequently preventing sulfur passivation of electrode. ${ }^{26,27}$

$14 \mathrm{~mL}$ inocula in brown color was fully mixed with $25 \mathrm{~g} \mathrm{~L}^{-1}$ of FeS power and added to the anode chamber of a double-chamber MFC reactor separated by proton exchange membrane (Nafion-117, DuPont Company, USA), followed by addition of anode medium to $28 \mathrm{~mL}$. Then, $28 \mathrm{~mL}$ phosphate buffer solution (PBS, $11.53 \mathrm{~g} \mathrm{~L}^{-1}$ $\mathrm{Na}_{2} \mathrm{HPO}_{4} \cdot 12 \mathrm{H}_{2} \mathrm{O}, 2.77 \mathrm{~g} \mathrm{~L}^{-1} \mathrm{NaH}_{2} \mathrm{PO}_{4} \cdot 2 \mathrm{H}_{2} \mathrm{O}, 0.31 \mathrm{~g} \mathrm{~L}^{-1} \mathrm{NH}_{4} \mathrm{Cl}$, and $\left.0.13 \mathrm{~g} \mathrm{~L}^{-1} \mathrm{KCl}\right)$ transferred to the cathode chamber $(28 \mathrm{~mL})$. Both anode and cathode were made of pretreated graphite felt, and connected by a piece of titanium wire across an external loading of $500 \Omega$. After the double-chamber MFC reactor above reached stable, the anode supernatant (here called real iron-laden stream and used in this study) was collected which contained $50.1 \mathrm{mmol} \mathrm{L}{ }^{-1} \mathrm{Fe}^{2+}$, $14.1 \mathrm{mmol} \mathrm{L}^{-1} \mathrm{Fe}^{3+}$ and $52.1 \mathrm{mmol} \mathrm{L}^{-1} \mathrm{SO}_{4}{ }^{2+}$ as well as ACB microbes. The $\mathrm{pH}$ value of real iron-laden stream was around 3.5.

\subsection{Operational}

For determination of the initial $\mathrm{pH}$ influence on electricity generation, three single-chamber MFC reactors were filled with 
$28 \mathrm{~mL}$ synthetic stream containing $50 \mathrm{mmol} \mathrm{L}{ }^{-1} \mathrm{Fe}^{2+}$ in an anaerobic glove box, and then the $\mathrm{pH}$ adjusted to 2.5 (MFC-2.5), 4.5 (MFC-4.5) and 6.5 (MFC-6.5) using $0.1 \mathrm{~mol} \mathrm{~L}^{-1} \mathrm{HCl}$ and $0.1 \mathrm{~mol} \mathrm{~L}^{-1} \mathrm{NaOH}$ solution, respectively. For the treatment of real iron-laden stream, the reactor (inoculated MFC) were filled with $28 \mathrm{~mL}$ real stream in an anaerobic glove box, and then the $\mathrm{pH}$ level adjusted to the optimal value determined above from 3.5. In order to investigate the role of ACB microbes carried by real ironladen stream, another reactor (Sterile control) was filled after filtrating by $0.2 \mu \mathrm{m}$ acetate fiber microfiltration membrane to remove ACB microbes from real iron-laden stream. All reactors were placed in a temperature-controlled room $\left(30^{\circ} \mathrm{C}\right)$.

The medium in the reactors was refilled when the cell voltage dropped below $20 \mathrm{mV}$. At the end of experiment, the precipitates at the bottom of reactors and on electrode surface were removed with a plastic plate and analyzed as follows. The solution was monitored for total iron and ferrous ions. The anode and cathode were softly washed using deionized water and air-dried at room temperature for the use of SEM (TM3030, HITACHI, Japan) observation. The precipitates were washed using deionized water and centrifuged three times at $3000 \mathrm{~g}$, and air-dried at room temperature for the use of XPS (AXIS HIS 165 spectrometer, Kratos Analytical) survey.

\subsection{Analysis}

The cell voltage $(V)$ across the external loading $(R)$ was automatically recorded by a computer-based data acquisition system (DAQ-2204, Taiwan ADLINK Ltd., China) at a pre-determined sampling frequency $(1 \mathrm{~h})$. The power output $(P)$, normalized by the projected surface area of the anode $(A)$, was calculated by the equation $P=V^{2}\left(R^{-1} \times A\right)$. After the reactors reached stable, cyclic voltammetry (CV) scanning of the anode was conducted using an electrochemical workstation (CHI600D, CH Instruments Inc., China) in depleted substrate condition. Before analysis, the reactors were left in open-circuit for $1 \mathrm{~h}$ to reach the static state. The working and counter terminals of the electrochemical instrument were connected in situ to the anode and cathode of the examined MFC reactor, while a saturated calomel electrode (SCE, +0.242 V vs. the standard hydrogen electrode [SHE], Gaoshirilian Ltd., China) as the reference electrode was placed close to the anode. Prior to use, SCE was carefully rinsed with deionized water. According to the working potential of the electrodes investigated here, $\mathrm{CV}$ was performed from $-0.9 \mathrm{~V}$ to $+0.9 \mathrm{~V} v s$. SCE at a scan rate of $1 \mathrm{mV} \mathrm{s}^{-1}$.

The concentrations of total iron were quantified at $248 \mathrm{~nm}$ by the flame atomic absorption spectrophotometry (AA-7000, SHIMADZU, Japan) equipped with a hollow cathode lamp (GL, SHIMADZU, Japan), and ferrous ions was by phenanthroline spectrophotometric method. ${ }^{28}$ If not analyzed immediately, the filtered samples were kept $\mathrm{pH}<2.5$ in closed vials to prevent the oxidization of ferrous to ferric ions or precipitation. At the end of experiment, the anode and cathode of the inoculated MFC reactor after dried were imaged using SEM. ${ }^{29}$ The precipitates of both anode and cathode of the inoculated MFC reactor were respectively recorded by XPS spectrometer equipped with a monochromatized Al Ka X-ray source (1486.71 eV photons).

\section{Results and discussion}

\subsection{Influence of initial $\mathrm{pH}$ on electricity generation from synthetic stream}

Due to the strong dependence of eqn (1) on solution $\mathrm{pH}$, the outputted cell voltages and power densities were firstly shown in Fig. 2 and 3 as varying initial pH of synthetic stream from 2.5 to 4.5 and 6.5 . The peak cell voltages of three single chamber air-cathode MFC reactors firstly experienced a rapid decline and then reached a platform, suggesting that electricity heavily depended on chemical reaction. The peak cell voltages of MFC2.5, MFC-4.5 and MFC-6.5 reactors presented to be 267.4, 352.4 and $189.6 \mathrm{mV}$. Accordingly, the power density along with initial

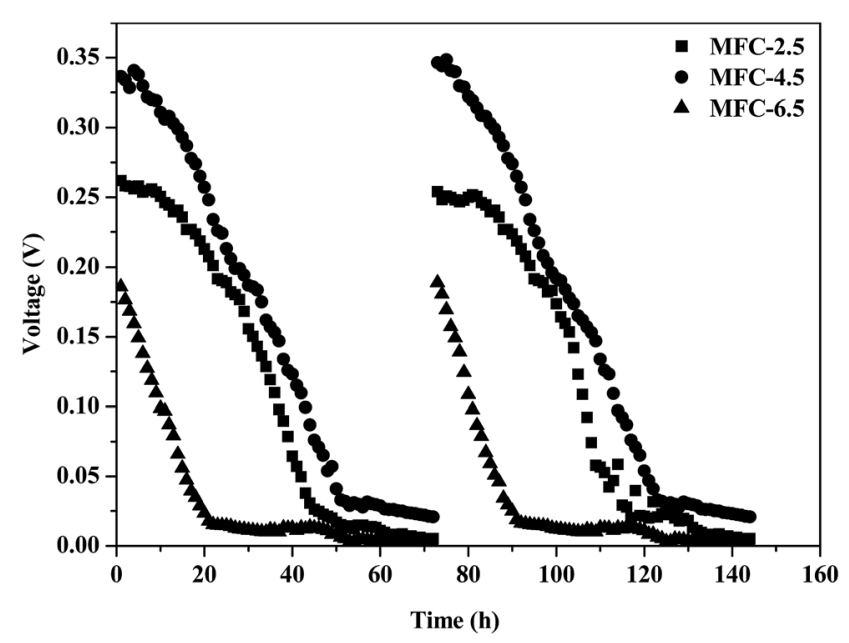

Fig. 2 Cell voltages generated from synthetic stream with $50 \mathrm{mmol}$ $\mathrm{L}^{-1} \mathrm{Fe}^{2+}$. Three reactors were filled with $28 \mathrm{~mL}$ synthetic stream in an anaerobic glove box, and then the $\mathrm{pH}$ adjusted to 2.5 (MFC-2.5), 4.5 (MFC-4.5) and 6.5 (MFC-6.5) using $0.1 \mathrm{~mol} \mathrm{~L}^{-1} \mathrm{HCl}$ and $0.1 \mathrm{~mol} \mathrm{~L}^{-1}$ $\mathrm{NaOH}$ solution, respectively.

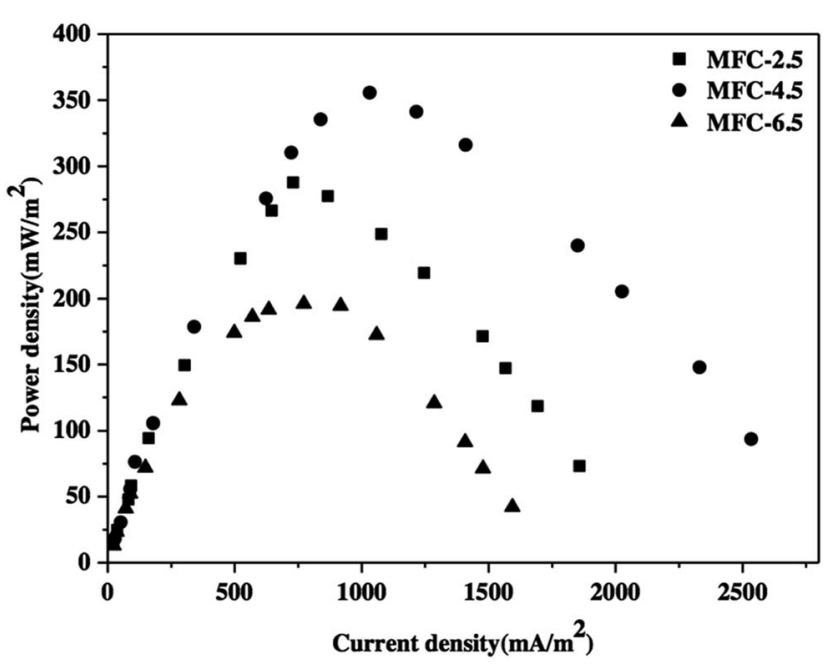

Fig. 3 Power density generated from synthetic stream. After the reactors were in open circuit for overnight, the power density curves were obtained by changing the external resistance in the range of 100 $\Omega$ to $100 \mathrm{k} \Omega$. 
$\mathrm{pH}$ variation was $139.5 \mathrm{~mW} \mathrm{~m}^{-2}$ for MFC-2.5, $298.9 \mathrm{~mW} \mathrm{~m}^{-2}$ for MFC-4.5 and $47.3 \mathrm{~mW} \mathrm{~m}^{-2}$ for MFC-6.5, which was negatively associated with the internal resistances (Fig. 3). The single chamber air-cathode MFC reactor with $\mathrm{pH}=4.5$ outperformed in electricity generation. The power generated at $\mathrm{pH}=4.5$ here was approximate to that of a double chamber fuel cell reactor with an anion exchange membrane treating synthetic ADM water at $\mathrm{pH}=6.3$, in which the maximum power density was $290 \mathrm{~mW} \mathrm{~m}{ }^{-2} \cdot{ }^{19}$ In the air-cathode MFC reactor, the cathode $\mathrm{pH}$ was always approximate to that of the anode, and the lower $\mathrm{pH}$ level supplied enough $\mathrm{H}^{+}$for the cathode reduction reaction. The shift of optimal pH from 6.3 of dual-chamber MFC to 4.5 here was possibly associated with the reactor structure, which could reduce the dosage of alkali.

At $25{ }^{\circ} \mathrm{C}$, the solubility product constant of $\mathrm{Fe}(\mathrm{OH})_{2}$ in aqueous solution was $8 \times 10^{-16} .^{30}$ Generally, when the iron ion concentration in aqueous solution was below $10^{-4} \mathrm{~mol} \mathrm{~L}^{-1}$, iron hydroxide $\left[\mathrm{Fe}(\mathrm{OH})_{2}\right]$ were regarded to completely precipitate via eqn (2). Accordingly, $\left[\mathrm{OH}^{-}\right]$were calculated to be around $10^{-6.5} \mathrm{~mol} \mathrm{~L}^{-1}$, indicating that the $\mathrm{pH}$ level higher than 7.5 was favorable for the precipitation of $\mathrm{Fe}(\mathrm{OH})_{2}$. The higher the $\mathrm{pH}$, the more the iron hydroxide precipitates. In our single chamber air-cathode MFC reactors, the initial $\mathrm{pH}$ was $2.5,4.5$ and 6.5 and lowered to $2.0,4.0$ and 6.0 at the end of each reaction cycle, suggesting that ferrous iron would not precipitate in the form of $\mathrm{Fe}(\mathrm{OH})_{2}$ via eqn (2). However, with the anode catalysis and electron transferring, ferrous ion easily deposited in the form of $\mathrm{Fe}(\mathrm{OH})_{3}$ via eqn (1) at the anode although this reaction was thermodynamically unfavorable with $\Delta_{\mathrm{f}} G^{0}=+77.49 \mathrm{~kJ} \mathrm{~mol}^{-1}$ under standard conditions $\left(\left[\mathrm{H}^{+}\right]=1 \mathrm{~mol} \mathrm{~L}^{-1}, \mathrm{pH}=0\right)$. Synchronously, oxygen was combined with $\mathrm{H}^{+}$(from streams or diffused from the anode) and electrons (transferred from the external circuit) into water at the cathode. Eqn (1) was strongly $\mathrm{pH}$ dependent, and increasing $\mathrm{pH}$ made it more favorable. When the initial $\mathrm{pH}$ in air-cathode $\mathrm{MFC}$ reactors increased to 4.5 from $2.5, \mathrm{Fe}(\mathrm{OH})_{3}$ was more favorable to deposit with the oxidization of ferrous ions. The outputted cell voltages in MFC4.5 reactor amounted to $352.4 \mathrm{mV}$ (Fig. 2). Also, at $\mathrm{pH}=2.5$, it was difficult for $\mathrm{Fe}(\mathrm{OH})_{3}$ to precipitate and recover iron, which further blocked the oxidization of ferrous to ferric ions, causing that the outputted cell voltage of MFC-2.5 was lower than that of MFC-4.5 reactor. The peak cell voltage of MFC-6.5 heavily turned down to $189.6 \mathrm{mV}$ from $352.4 \mathrm{mV}$ of MFC-4.5. Although not well understood, it was possibly associated with $\left[\mathrm{H}^{+}\right]$ decrease at $\mathrm{pH}=6.5$, which made cathode oxygen reduction lowered, consequently decreasing the outputted cell voltage.

$\mathrm{Fe}^{2+}+2 \mathrm{H}_{2} \mathrm{O} \rightarrow \mathrm{Fe}(\mathrm{OH})_{2} \downarrow+2 \mathrm{H}^{+},\left(\Delta_{\mathrm{f}} G^{0}=+57.95 \mathrm{~kJ} \mathrm{~mol}^{-1}\right)$

\subsection{Electricity generation and iron recovery from real iron- laden stream}

As revealed above, the single chamber air-cathode MFC reactor at $\mathrm{pH}=4.5$ achieved the highest cell voltage when treating synthetic stream with $50 \mathrm{mmol} \mathrm{L}{ }^{-1} \mathrm{Fe}^{2+}$. We replaced synthetic stream using real iron-laden stream containing $50.1 \mathrm{mmol} \mathrm{L}^{-1}$ $\mathrm{Fe}^{2+}, 14.1 \mathrm{mmol} \mathrm{L}^{-1} \mathrm{Fe}^{3+}$ and $52.1 \mathrm{mmol} \mathrm{L}^{-1} \mathrm{SO}_{4}{ }^{2+}$ as well as
ACB microbes. It showed that the peak cell voltage was $360.1 \mathrm{mV}$ for the inoculated MFC reactor and $314.6 \mathrm{mV}$ for the Sterile control (Fig. 4). Accordingly, the power densities were 343.31 $\mathrm{mW} \mathrm{m} \mathrm{m}^{-2}$ for the inoculated MFC reactor and $265.64 \mathrm{~mW} \mathrm{~m}^{-2}$ for the Sterile control. In the presence of ACB microbes, the power density was increased by $29.2 \%$. A couple of redox peaks with the potentials of about $-0.1 \mathrm{~V}$ and $+0.1 \mathrm{~V}$, which was in agreement with that of biofilm, ${ }^{27}$ was observed in $\mathrm{CV}$ curve of the inoculated anode (Fig. 5). It demonstrated that the anode biofilm with redox species formed due to the presence of ACB microbes carried by real iron-laden stream, and further

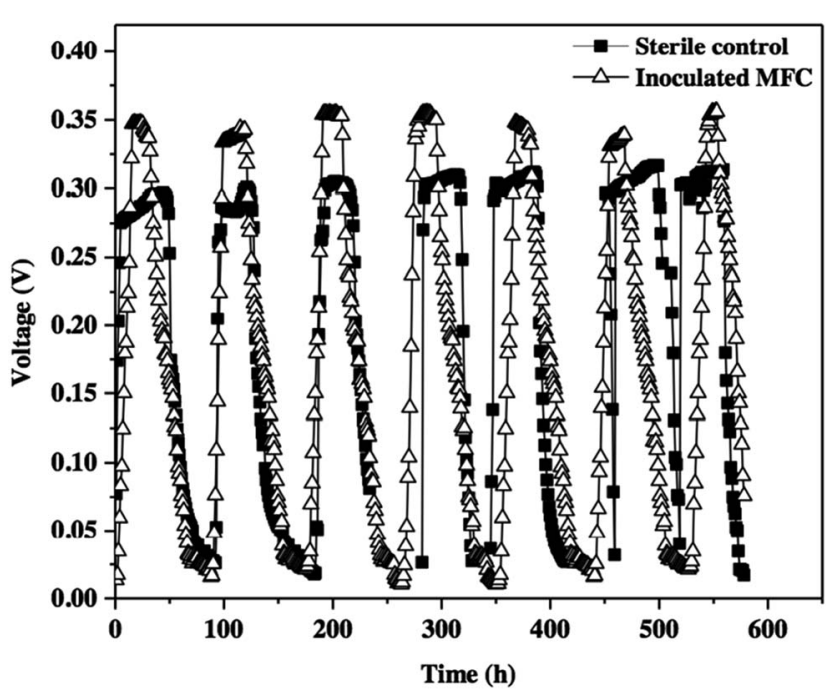

Fig. 4 Cell voltage generated from real iron-laden stream. The real stream used here was obtained by bioleaching FeS power as previously described in our lab, which contained $50.1 \mathrm{mmol} \mathrm{L}^{-1} \mathrm{Fe}^{2+}, 14.1 \mathrm{mmol}$ $\mathrm{L}^{-1} \mathrm{Fe}^{3+}$ and $52.1 \mathrm{mmol} \mathrm{L}^{-1} \mathrm{SO}_{4}{ }^{2+}$ as well as ACB microbes. The $\mathrm{pH}$ value was around 3.5 .

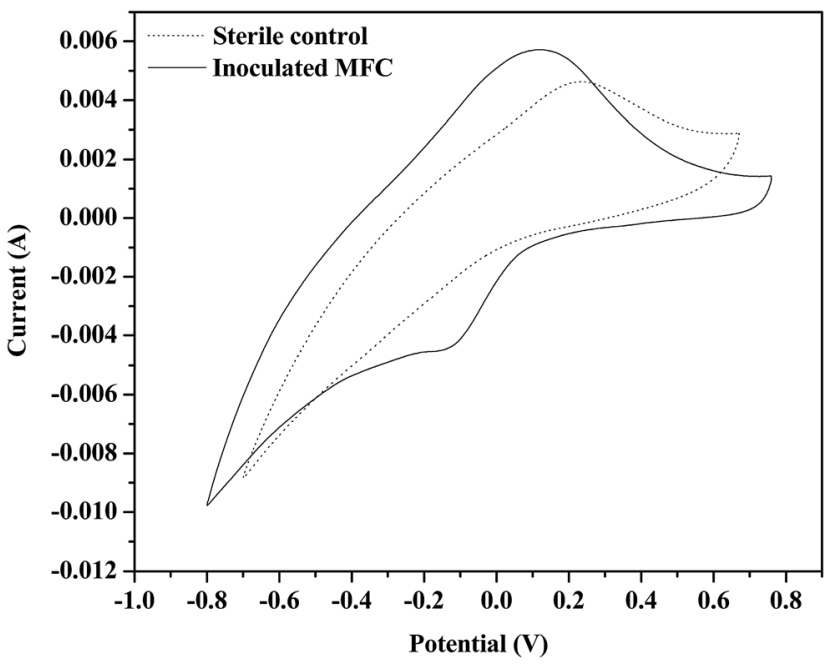

Fig. $5 \mathrm{CV}$ curves of real stream system. After the reactors reached stable, CV scanning was conducted using an electrochemical workstation in depleted substrate condition. Before analysis, the reactors were left in open-circuit for $1 \mathrm{~h}$ to reach the static state. 
promoted electrons transferring. ${ }^{31}$ While, in CV curve of the Sterile anode, there was no redox peak, showing that it presented no electrochemical activity substances.

In single chamber air-cathode MFC reactors, $\mathrm{SO}_{4}{ }^{2-}$ was as high as $52.1 \mathrm{mmol} \mathrm{L}^{-1}$ and could be reduced to $\mathrm{S}^{0}$ via eqn (3) $\left(\Delta_{\mathrm{f}} G^{0}=-193.66 \mathrm{~mol} \mathrm{~L}^{-1}\right)$, and $\mathrm{S}^{0}$ deposition usually led to electrode passivation ${ }^{32}$ and further inhibited electricity generation. Different from well-known microbes, such as sulfatereducing bacteria, ${ }^{33} \mathrm{ACB}$ microbes could grow well in strong acid solution and tolerated high-strength metals under both anaerobic and aerobic environment. ${ }^{24,25}$ Importantly, ACB microbes had ability to take $\mathrm{S}^{0}$ as electron donor (during which $\mathrm{S}^{0}$ was oxidized to $\mathrm{SO}_{4}{ }^{2-}$ ) and ferric ions or electrode as electron acceptor, consequently preventing eqn (3) to happen. ${ }^{26,27}$ Therefore, the presence of ACB microbes in the inoculated MFC reactor made sulfur passivation of electrode avoidable and the outputted cell voltage was higher than that of the Sterile control. It also was higher than that of a double chamber fuel cell reactor treating synthetic ADM water with no microbes. ${ }^{19}$

$\mathrm{SO}_{4}{ }^{2-}+8 \mathrm{H}^{+}+6 \mathrm{e}^{-} \rightarrow \mathrm{S}^{0} \downarrow+4 \mathrm{H}_{2} \mathrm{O},\left(\Delta_{\mathrm{f}} G^{0}=-193.66 \mathrm{~mol} \mathrm{~L}^{-1}\right)$

At the end of experiment, the total iron ion concentration decreased to $1218.6 \mathrm{mg} \mathrm{L}^{-1}$ for the Sterile control and $1012.3 \mathrm{mg}$ $\mathrm{L}^{-1}$ for the inoculated MFC reactor, respectively, from $3595.2 \mathrm{mg}$ $\mathrm{L}^{-1}$ at the beginning of experiment (Table 1). The iron recovery rate was calculated to be $66.1 \%$ for the Sterile control and $71.8 \%$ for the inoculated MFC reactor by precipitating on the anode and cathode as well as at the bottom of reactors. Accordingly, the total iron precipitates collected were $184.0 \mathrm{mg}$ and $196.0 \mathrm{mg}$ (Table 1) and was light-brown color to the naked eyes (Fig. S1 $\dagger$ ), and the anode precipitates amounted for $83.2 \%$ and $83.7 \%$, respectively. It showed that the iron recovery mainly completed on the anode and was dominated by eqn (1), which was in agreement with the results of Cheng et al. ${ }^{19}$ In addition, the ferrous ion concentration in the inoculated MFC reactor decreased to $114.4 \mathrm{mg} \mathrm{L}^{-1}$ from $2805.6 \mathrm{mg} \mathrm{L}^{-1}$, showing the removal rate of ferrous iron was as high as $95.9 \%$.

With $95.9 \%$ ferrous ions removed in the inoculated MFC reactor, there was $1.35 \mathrm{mmol}$ electrons released to the anode (eqn (1)). Based on the cell voltage across $500 \Omega$ external resistance, the current generated was equivalent to $1.19 \mathrm{mmol}$

Table 1 Distribution of iron in the sterile control and inoculated MFC reactors at $\mathrm{pH}=4.5$ before and after operation. The reactors were filled with real stream containing $50.1 \mathrm{mmol} \mathrm{L}^{-1} \mathrm{Fe}^{2+}, 14.1 \mathrm{mmol} \mathrm{L}{ }^{-1}$ $\mathrm{Fe}^{3+}$ and $52.1 \mathrm{mmol} \mathrm{L}^{-1} \mathrm{SO}_{4}{ }^{2+}$ as well as ACB microbes

\begin{tabular}{lll}
\hline Items & $\begin{array}{l}\text { Sterile } \\
\text { control }\end{array}$ & $\begin{array}{l}\text { Inoculated } \\
\text { MFC reactor }\end{array}$ \\
\hline Initial concentration of total iron $\left(\mathrm{mg} \mathrm{L}^{-1}\right)$ & 3614.3 & 3614.3 \\
Final concentration of total iron $\left(\mathrm{mg} \mathrm{L}^{-1}\right)$ & 1218.6 & 1012.3 \\
Anode precipitate $(\mathrm{mg})$ & 153 & 164 \\
Cathode precipitate $(\mathrm{mg})$ & 19 & 26 \\
Precipitate at the reactor bottom $(\mathrm{mg})$ & 12 & 6 \\
Sum of precipitate $(\mathrm{mg})$ & 184 & 196
\end{tabular}

electrons over one stable reaction cycle, and the coulombic efficiency of the inoculated MFC reactor was calculated to be $88.1 \%$ higher than $72 \%$ obtained using bacteria and acetate. ${ }^{34}$ However, the ferrous removal and coulombic efficiency here were slightly lower than the literature. ${ }^{19}$ It might be attributed to oxygen diffusion to the anode from the air cathode and the presence of unknown electron acceptors in real streams. Anyway, it demonstrated that single chamber air-cathode MFC technology had potential to synchronously recover metal and electricity from real metal-laden streams.

\subsection{SEM observation and XPS analysis of precipitate and electrodes}

At the end of experiment, the precipitates of the anode and cathode as well as the anode surface of the inoculated MFC reactor after air-dried were observed using SEM (Fig. 6), and the precipitates was surveyed using XPS (Fig. 7). As can be seen, the anode precipitate presented to be coarse with some bumps (Fig. 6a). The cathode precipitate grew a large amount of irregular solid pellets or flocs (Fig. 6b), suggesting that the anode precipitate was different from the cathode. Additionally, the anode surface was covered by rod-shaped bacteria (Fig. 6c), which was in agreement with the electro-active biofilm formation (Fig. 5). The anode precipitate contained $\mathrm{O}, \mathrm{Fe}, \mathrm{Na}, \mathrm{Mg}, \mathrm{Cl}$ and $\mathrm{S}$ elements as revealed by the XPS survey (Fig. 7a), and the $\mathrm{O}$ absorption peak was strongest followed by that of Fe element. It indicated that the anode precipitate mainly contained $\mathrm{O}$ and $\mathrm{Fe}$ elements, probably were iron oxides carrying a small amount of sodium and magnesium salts in. In XPS spectra, the absorption peak of $\mathrm{O}$ element appeared at the binding energy of around $531.1 \mathrm{eV}$, and $\mathrm{O}$ element here was attributed to iron(III) hydroxide oxide $(\mathrm{FeOOH}){ }^{35}$ The absorption peak of Fe element occurred at the binding energy of around $710.1 \mathrm{eV}$, which was also attributed to iron(III) hydroxide oxide (FeOOH). ${ }^{36}$ It concluded that the anode precipitate was dominated by iron(III) hydroxide oxide $(\mathrm{FeOOH})$, which was in agreement with the result of Cheng et al. ${ }^{20}$ In addition, a weak absorption peak of $\mathrm{S}$ element appeared at the binding energy of $169.1 \mathrm{eV}$ in the XPS spectra, suggesting that there was a small amount of sulfate in the anode precipitate. ${ }^{37}$ There was no $\mathrm{S}^{0}$ detected in the anode precipitate according to Lindberg et al. ${ }^{38}$ which was possibly associated with ACB microbes presented in real iron-laden stream.

The XPS spectra of cathode precipitate was revealed in Fig. 7b. There were $\mathrm{O}, \mathrm{Fe}, \mathrm{S}, \mathrm{K}, \mathrm{Na}, \mathrm{Mg}$ and $\mathrm{Cl}$ elements, which was slightly complicated than that of the anode precipitate. $\mathrm{O}$ and Fe elements still remained to be dominant. Different from Fe spectra of anode, the absorption peak of Fe element occurred at the binding energy of around $712.1 \mathrm{eV}$, and was regarded to be from iron(III) oxide. ${ }^{39} \mathrm{O}$ element was from metallic oxide because the binding energy was at around $532.1 \mathrm{eV}{ }^{40}$ It suggested that, different from the anode precipitate, the cathode precipitate mainly contained $\mathrm{Fe}_{2} \mathrm{O}_{3}$. Similarly, the $\mathrm{S}$ absorption peak revealed to be sulfate, ${ }^{37}$ but not $S^{0}$.

In the cathode precipitate, because there was a certain amount of $\mathrm{K}$ element and the $\mathrm{S}$ absorption peak was heavily 

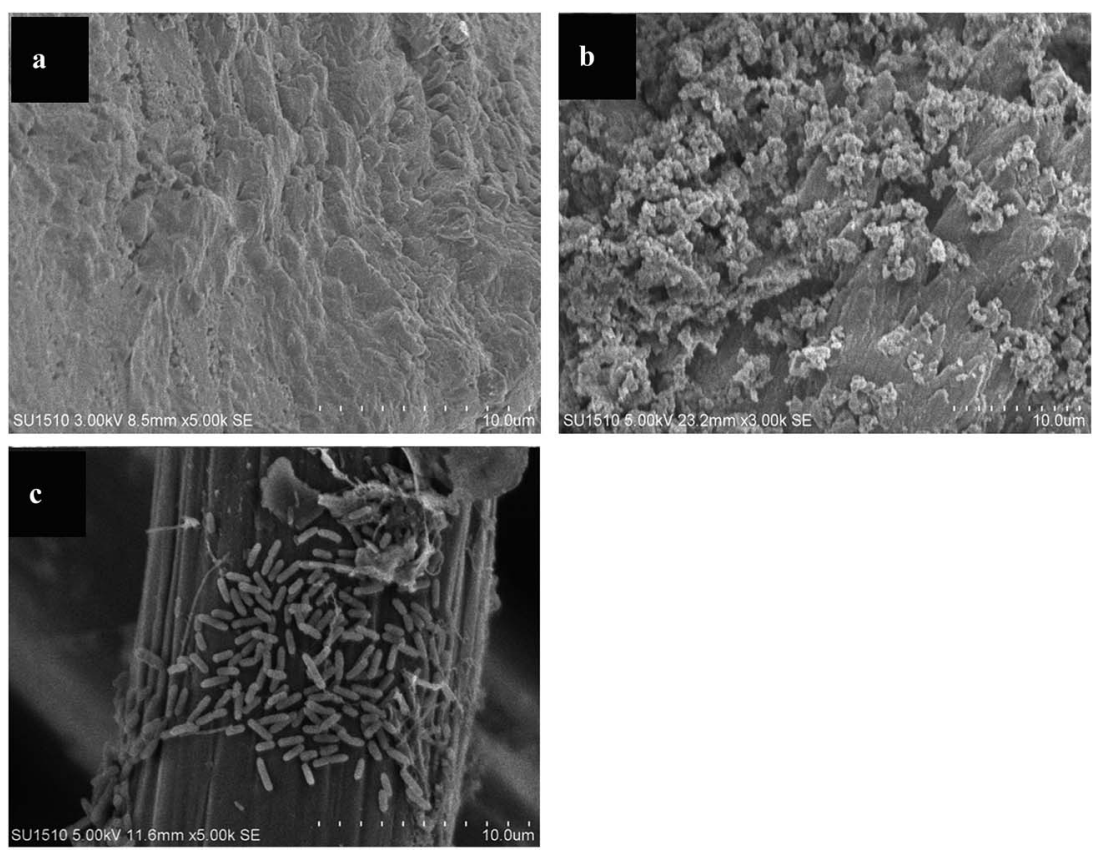

Fig. 6 SEM images of the precipitates from anode (a) and cathode (b) as well as anode surface (c) of the inoculated MFC reactor at the end of experiment.

stronger than that of the anode precipitate, we speculated that jarosite $\left[\mathrm{KFe}_{3}\left(\mathrm{SO}_{4}\right)_{2}(\mathrm{OH})_{6}\right]$ precipitated via eqn (4) with the thermodynamic favorable free energy $\left(\Delta_{\mathrm{f}} G^{0}=-135.45 \mathrm{~kJ} \mathrm{~mol}^{-1}\right)$. Further, the jarosite electrode passivation possibly took place. ${ }^{\mathbf{4 1}}$ However, jarosite dissolution reactions (eqn (5) and (6)) in lower $\mathrm{pH}$ solution were also thermodynamically favorable with the free energies of -116.50 and $-93.70 \mathrm{~kJ} \mathrm{~mol}^{-1}$, respectively.

$$
\begin{array}{r}
2 \mathrm{Fe}(\mathrm{OH})_{3}+\mathrm{K}^{+}+\mathrm{Fe}^{3+}+2 \mathrm{SO}_{4}{ }^{2-} \rightarrow \mathrm{KFe}_{3}\left(\mathrm{SO}_{4}\right)_{2}(\mathrm{OH})_{6} \downarrow \\
\left(\Delta_{\mathrm{f}} G^{0}=-135.45 \mathrm{~kJ} \mathrm{~mol}^{-1}\right)
\end{array}
$$

$$
\begin{array}{r}
\mathrm{KFe}_{3}\left(\mathrm{SO}_{4}\right)_{2}(\mathrm{OH})_{6}+8 \mathrm{H}^{+}+3 \mathrm{e}^{-} \rightarrow \mathrm{K}^{+}+3 \mathrm{Fe}^{2+}+2 \mathrm{HSO}_{4}^{-} \\
+6 \mathrm{H}_{2} \mathrm{O},\left(\Delta_{\mathrm{f}} G^{0}=-116.50 \mathrm{~kJ} \mathrm{~mol}^{-1}\right)
\end{array}
$$

$\mathrm{KFe}_{3}\left(\mathrm{SO}_{4}\right)_{2}(\mathrm{OH})_{6}+6 \mathrm{H}^{+}+3 \mathrm{e}^{-} \rightarrow \mathrm{K}^{+}+3 \mathrm{Fe}^{2+}+2 \mathrm{SO}_{4}^{2-}+6 \mathrm{H}_{2} \mathrm{O}$,

$$
\left(\Delta_{\mathrm{f}} G^{0}=-93.70 \mathrm{~kJ} \mathrm{~mol}^{-1}\right)
$$

Based on eqn (7), the reduction potential $\left(E^{0}\right)$ was calculated to be $+0.402 \mathrm{~V}$ for eqn (5) and $+0.324 \mathrm{~V}$ for eqn (6) under standard conditions. The potential under nonstandard conditions could be given by Nernst equation. Jarosite dissolution reactions (eqn (5) and (6)) were $\mathrm{pH}$ dependent, and increasing $\mathrm{pH}$ made the reaction more unfavorable. Under our experiment conditions of $\mathrm{pH}=4.5,\left[\mathrm{~K}^{+}\right]=0.67 \times 10^{-3} \mathrm{~mol} \mathrm{~L}^{-1},\left[\mathrm{Fe}^{2+}\right]=$ $0.050 \mathrm{~mol} \mathrm{~L}^{-1},\left[\mathrm{SO}_{4}{ }^{2-}\right]=0.052 \mathrm{~mol} \mathrm{~L}^{-1}$ and $T=303 \mathrm{~K}$, the reduction potential was calculated to be $-0.115 \mathrm{~V}$ for eqn (5) and $-0.017 \mathrm{~V}$ for eqn (6). It meant that jarosite dissolution reactions only happened at the anode. Therefore, there was no $\mathrm{K}$ element detected in the anode precipitate and a weaker $\mathrm{S}$ absorption peak. In the inoculated MFC reactor, not only was there no sulfur passivation of electrodes, but also there was no jarosite passivation, although real iron-laden stream contained $0.052 \mathrm{~mol} \mathrm{~L}^{-1} \mathrm{SO}_{4}{ }^{2-}$.
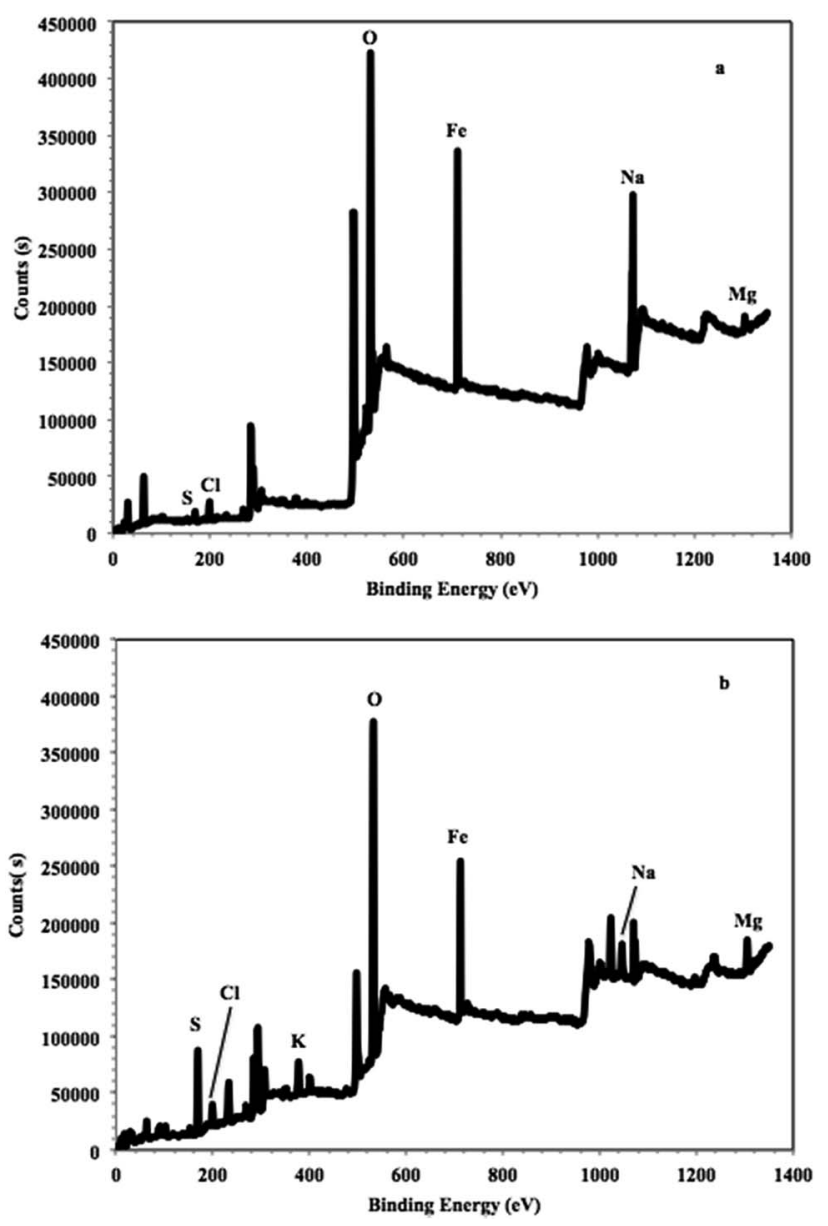

Fig. 7 XPS survey of anode (a) and cathode (b) precipitates recovered from the inoculated MFC reactor. Before analysis, precipitates were air-dried at room temperature. 
Table 2 Reaction equations and their thermodynamics parameters involved in iron recovery using single chamber air-cathode MFC reactors. The free energy $\left(\Delta_{\mathrm{f}} G^{0}\right)$ was calculated based on thermodynamic data, and potentials under standard and nonstandard conditions were calculated using Nernst equation

\begin{tabular}{lllll}
\hline Reaction equations & $\Delta_{\mathrm{f}} G^{0}\left(\mathrm{~kJ} \mathrm{~mol}^{-1}\right)$ & $E^{0}(\mathrm{~V})$ & Potential equations & $E^{\prime}$ at $\mathrm{pH}=4.5(\mathrm{~V})$ \\
\hline
\end{tabular}

\section{Anode reactions}
(a) $\mathrm{Fe}^{2+}+3 \mathrm{H}_{2} \mathrm{O} \rightarrow \mathrm{Fe}(\mathrm{OH})_{3} \downarrow+3 \mathrm{H}^{+}+\mathrm{e}^{-}$
(b) $\mathrm{Fe}^{2+} \rightarrow \mathrm{Fe}^{3+}+\mathrm{e}^{-}$
(c) $\mathrm{Fe}^{2+}+2 \mathrm{e}^{-} \rightarrow \mathrm{Fe} \downarrow$
(d) $\mathrm{Fe}^{3+}+3 \mathrm{e}^{-} \rightarrow \mathrm{Fe} \downarrow$
(e) $\mathrm{Fe}^{3+}+3 \mathrm{H}_{2} \mathrm{O} \rightarrow \mathrm{Fe}(\mathrm{OH})_{3} \downarrow+3 \mathrm{H}^{+}$

-0.803
-0.769
-0.409
-0.016
-

+1.229
+0.894
+0.769
-
$E=-0.800+0.006 \mathrm{pH}$

$E=-0.726$

$E=-0.447$

$E=-0.052$

$-$
-0.773
-0.726
-0.447
-0.052
-

$E=+1.229-0.060 \mathrm{pH}$
$E=+0.846$
$E=+0.736$
$+0.959$

$+0.846$

$+0.736$$$
-
$$

(h) $\mathrm{Fe}^{3+}+\mathrm{e}^{-} \rightarrow \mathrm{Fe}^{2+}$

\subsection{Mechanism analysis of iron recovery in single chamber air-cathode MFC reactors}

Based on the results and discussion above, the possible reactions associated with iron recovery in single chamber aircathode MFC reactors treating real iron-laden stream were listed in Table 2 . The reaction free energy $\left(\Delta_{\mathrm{f}} G^{0}\right)$ was calculated according to the thermodynamic data ${ }^{30}$ and the potentials under standard conditions were obtained for the reduction and oxidization reactions via eqn (7).

Under our experiment conditions of $\mathrm{pH}=4.5,\left[\mathrm{Fe}^{3+}\right]=$ $0.014 \mathrm{~mol} \mathrm{~L}^{-1},\left[\mathrm{Fe}^{2+}\right]=0.050 \mathrm{~mol} \mathrm{~L}^{-1}$ and $T=303 \mathrm{~K}$, the ferrous oxidization to $\mathrm{Fe}(\mathrm{OH})_{3}$ precipitate [eqn (a) in Table 2] with $E^{\prime}=$ $-0.773 \mathrm{~V}$ was most favorable and followed by the ferrous oxidization to ferric ions [eqn (b)] with $E^{\prime}=-0.726 \mathrm{~V}$. In the single chamber air-cathode MFC combined electricity generation with iron recovery from real iron-laden stream in this manuscript, ferrous iron, instead of organic substrates, was used as electron donor. At $25{ }^{\circ} \mathrm{C}$, the solubility product constant of $\mathrm{Fe}(\mathrm{OH})_{3}$ in aqueous solution was $4 \times 10^{-38} \cdot{ }^{30}$ Accordingly, $\left[\mathrm{OH}^{-}\right]$were calculated to be around $10^{-11.5} \mathrm{~mol} \mathrm{~L}^{-1}$, indicating that the $\mathrm{pH}$ level higher than 2.5 was favorable for the precipitation of $\mathrm{Fe}(\mathrm{OH})_{3}$. Therefore, the ferric ions also precipitated in the form of $\mathrm{Fe}(\mathrm{OH})_{3}$ at $\mathrm{pH}>2.5$ [eqn (e)].

Further, $\mathrm{Fe}(\mathrm{OH})_{3}$ was lost water to $\mathrm{FeOOH}$, as demonstrated by anode XPS spectra (Fig. 7a). Additionally, the free energies $\left(\Delta_{\mathrm{f}} G^{0}\right)$ of ferrous and ferric reduction to metallic $\mathrm{Fe}(0)$ [eqn (c) and (d)] were +78.87 and $+4.70 \mathrm{~kJ} \mathrm{~mol}^{-1}$ under standard conditions, ${ }^{30}$ and the corresponding potentials $\left(E^{0}\right)$ were -0.409 and $-0.016 \mathrm{~V}$, respectively. Compared with the potential of eqn (a) in Table 2, the formation of metallic $\mathrm{Fe}(0)$ was not competitive at the anode, especially at $\mathrm{pH}=4.5\left[\mathrm{Fe}(\mathrm{OH})_{3}\right.$ completely precipitated]. To avoid metallic $\mathrm{Fe}(0)$ formation at the anode and keep sustainable electricity generation, the solution $\mathrm{pH}$ should be kept at higher value. From Table 2, the reduction of oxygen via accepting electrons transferred from the anode [eqn (f)] was most favorable at the cathode and followed by the formation of $\mathrm{FeO}$ [eqn (h)]. Further, the $\mathrm{FeO}$ oxidization to $\mathrm{Fe}_{2} \mathrm{O}_{3}$ [eqn (i)] in the presence of $\mathrm{O}_{2}$ was also thermodynamically favorable $\left(\Delta_{\mathrm{f}} G^{0}=-560.66 \mathrm{~kJ} \mathrm{~mol}^{-1}\right)$, and, therefore, the cathode precipitate was dominated by $\mathrm{Fe}_{2} \mathrm{O}_{3}$ (Fig. 7b). It meant that $\mathrm{Fe}_{2} \mathrm{O}_{3}$ was directly produced through ferrous oxidization using oxygen at the cathode.

Both $\mathrm{FeOOH}$ (goethite) and $\mathrm{Fe}_{2} \mathrm{O}_{3}$ were conductive and their precipitation on the anode or cathode would not influence the sustainable electricity generation. At the anode of single chamber air-cathode MFC reactors treating real iron-laden stream, the higher $\mathrm{pH}(>2.5)$ should be kept to completely precipitate $\mathrm{Fe}(\mathrm{OH})_{3}$ and the anode product was controlled to be higher-grade $\mathrm{FeOOH}$. To ensure that $\mathrm{Fe}_{2} \mathrm{O}_{3}$ dominated the cathode precipitate, enough oxygen should be supplied at the cathode.

\section{Conclusions}

The single chamber air-cathode MFC combined electricity generation with iron recovery from real iron-laden stream in this manuscript. Ferrous iron, instead of organic substrates, was used as electron donor, which made it applicable for the (bio)leachate and mining/metallurgical stream sites possibly lack of organics. Using the synthetic stream, the optimal initial $\mathrm{pH}$ of air-cathode MFC solution was determined to be 4.5 with $352.4 \mathrm{mV}$ of cell voltage and $298.9 \mathrm{~mW} \mathrm{~m}^{-2}$ of power density. Without organic substrates as electron donor, $71.8 \%$ iron was recovered, $95.9 \%$ ferrous ions was removed and $343.31 \mathrm{~mW} \mathrm{~m}^{-2}$ power density were generated from real iron-laden stream at $\mathrm{pH}=4.5$. ACB microbes carried in real iron-laden stream was able to make the anode biofilm electrochemically active and further promote the electron transferring, and prevent sulfur passivation of electrodes via inhibiting sulfate reduction to $\mathrm{S}^{0}$. Ferrous ions were mainly oxidized to $\mathrm{Fe}(\mathrm{OH})_{3}$ at the anode and recovered by $\mathrm{FeOOH}$. In the presence of oxygen, ferrous ions directly combined with oxygen and electrons into $\mathrm{FeO}$, and further into $\mathrm{Fe}_{2} \mathrm{O}_{3}$ at the cathode. After optimization of system, it was prospective to recover metals and electricity from real streams, which contained high-strength metal, sulfate, strong 
acid and ACB microbes, using single chamber air-cathode MFC technology.

\section{Acknowledgements}

This work was supported by a grant from the Research and Innovation Project for Postgraduates of Higher Education Institutions of Jiangsu Province (No. KYLX14_1159, KYLX16_0812 and SJZZ16_0216).

\section{References}

1 Y. Asensio, C. M. Fernandez-Marchante, J. Lobato, P. Cañizares and M. A. Rodrigo, Water Res., 2016, 99, 16-23.

2 C. H. Feng, L. Q. Huang, H. Yu, X. Y. Yi and C. H. Wei, Water Res., 2015, 76, 160-170.

3 N. Montpart, L. Rago, J. A. Baeza and A. Guisasola, Water Res., 2015, 68, 601-615.

4 J. Llanos, P. M. Williams, S. Cheng, D. Rogers, C. Wright, Á. Pérez and P. Cañizares, Water Res., 2010, 44, 3522-3530.

5 R. M. Ruan, X. Y. Liu, G. Zou, J. H. Chen, J. K. Wen and D. Z. Wang, Hydrometallurgy, 2011, 108, 130-135.

6 G. Lofrano, M. Carotenuto, G. Libralato, R. F. Domingos, A. Markus, L. Dini, R. K. Gautam, D. Baldantoni, M. Rossi, S. K. Sharma, M. C. Chattopadhyaya, M. Giugni and S. Meric, Water Res., 2016, 92, 22-37.

7 H. T. Q. Kieu, E. Müller and H. Horn, Water Res., 2011, 45, 3863-3870.

8 K. R. Fradler, I. Michie, R. M. Dinsdale, A. J. Guwy and G. C. Premier, Water Res., 2014, 55, 115-125.

9 Y. V. Nancharaiah, S. Venkata Mohan and P. N. L. Lens, Bioresour. Technol., 2015, 195, 102-114.

10 H. M. Wang and Z. J. Ren, Water Res., 2014, 66, 219-232.

11 A. ter Heijne, F. Liu, R. V. Weijden, J. Weijma, C. J. Buisman and H. V. Hamelers, Environ. Sci. Technol., 2010, 44, 4376-4381.

12 L. Huang, J. Chen, X. Quan and F. Yang, Bioprocess Biosyst. Eng., 2010, 33, 937-945.

13 Y. Li, Y. Wu, S. Puranik, Y. Lei, T. Vadas and B. Li, J. Power Sources, 2014, 269, 430-439.

14 H. C. Tao, M. Liang, W. Li, L. J. Zhang, J. R. Ni and W. M. Wu, J. Hazard. Mater., 2011, 189, 186-192.

15 G. Wang, L. Huang and Y. Zhang, Biotechnol. Lett., 2008, 30, 1959-1966.

16 B. Zhang, C. Feng, J. Ni, J. Zhang and W. Huang, J. Power Sources, 2012, 204, 34-39.

17 C. Choi and N. Hu, Bioresour. Technol., 2013, 133, 589-598.

18 C. Abourached, T. Catal and H. Liu, Water Res., 2014, 51, 228-233.
19 S. A. Cheng, B. A. Dempsey and B. E. Logan, Environ. Sci. Technol., 2007, 41, 8149-8153.

20 S. A. Cheng, J. H. Jang, B. A. Dempsey and B. E. Logan, Water Res., 2011, 45, 303-307.

21 S. Panda, A. Akcil, N. Pradhan and H. Deveci, Bioresour. Technol., 2015, 196, 694-706.

22 P. F. Nie, X. F. Li, Y. P. Ren and X. H. Wang, RSC Adv., 2015, 5, 89062-89068.

23 G. Akinci and D. E. Guven, Desalination, 2011, 268(1-3), 221226.

24 L. G. Leduc, G. D. Ferroni and J. T. Trevors, World J. Microbiol. Biotechnol., 1997, 13(4), 453-455.

25 J. T. Pronk, K. Liem, P. Bos and J. G. Kuenen, Appl. Environ. Microbiol., 1991, 57, 2063-2068.

26 Y. M. Gong, A. Ebrahim, M. F. Adam, E. Mallory, T. Zhang, L. Derek and Z. Karsten, Environ. Sci. Technol., 2012, 47, 568-573.

27 A. ter Heijne, H. V. M. Hamelers and C. J. N. Buisman, Environ. Sci. Technol., 2007, 41(11), 4130-4134.

28 Y. D. Liu, S. H. Guo, R. L. Yu, K. Zou and G. Z. Qiu, Curr. Microbiol., 2014, 68(3), 285-292.

29 G. H. Gu, K. L. Zhao, G. Z. Qiu, Y. H. Hu and X. J. Sun, Hydrometallurgy, 2009, 100(1-2), 72-75.

30 J. G. Speight, Lange's Handbook of Chemistry, McGraw-Hill Education, New York, 16th edn, 2005, ISBN 0071432205.

31 X. Qian, Biochim. Biophys. Acta, Bioenerg., 2011, 1807(4), 404412.

32 T. Biegler and D. Swift, J. Appl. Electrochem., 1979, 9(5), 545554.

33 O. J. Hao, L. Huang, J. M. Chen and R. L. Buglass, Toxicol. Environ. Chem., 1994, 46, 197-212.

34 J. R. Kim, S. Cheng, S. E. Oh and B. E. Logan, Environ. Sci. Technol., 2007, 41, 1004-1009.

35 N. S. McIntyre, D. G. Zetaruk and D. Owen, Appl. Surf. Sci., 1978, 2(1), 55-73.

36 G. C. Allen, M. T. Curtis, A. J. Hooper and P. M. J. Tucker, J. Chem. Soc., Dalton Trans., 1974, 14, 1525-1530.

37 K. Arata and M. Hino, Appl. Catal., 1990, 59, 197-204.

38 B. J. Lindberg, K. Hamrin, G. Johansson, U. Gelius, A. Fahlmann, C. Nordling and K. Siegbahn, Phys. Scr., 1970, 1(5-6), 286-298.

39 P. Mills and J. L. J. Sullivan, J. Phys. D: Appl. Phys., 1983, 16(5), 723-732.

40 M. S. Raven, Surf. Interface Anal., 1979, 1, 20-25.

41 K. Sasaki, Y. Nakamuta, T. Hirajima and O. H. Tuovinen, Hydrometallurgy, 2009, 95(1-2), 153-158. 